\title{
28 Resarch Soure \\ Prion peptide alters calcium levels to damage neurons through autophagy
}

Ji-Hong Moon

Sang-Youel Park

\section{Video Byte}

Keywords: Calcium, Prion, Autophagy flux, Neurodegeneration, AMPK, autophagy, neuron, Cell Communication and Signaling

Posted Date: November 3rd, 2020

DOl: https://doi.org/10.21203/rs.3.rs-102135/v1

License: (c) (1) This work is licensed under a Creative Commons Attribution 4.0 International License. Read Full License 


\section{Abstract}

One hallmark of neurodegenerative diseases such as Alzheimer's and Parkinson's is protein accumulation in the brain. That accumulation is driven by structural modification of the cellular prion protein. which produces self-generating particles in the brain. Neuronal cell death caused by these protein clusters occurs through autophagy, the body's way of degrading damaged cells. Unfortunately, the pathways mediating prion-driven autophagy in neurons remain unclear. A recent study evaluated the role of calcium signaling - a common signaling pathway affected by prion proteins. Using neuronal cells from mice, researchers measured calcium signaling and the levels of proteins involved in metabolic stress and autophagy. Their results showed that human prion peptide increased the concentration of calcium in neurons. Inhibiting this prion-mediated calcium uptake in neurons prevented autophagic cell death. and preserved the activity of a protein called AMPK, which is involved in maintaining energy balance in cells. Although further in vivo studies are needed, the results suggest that intracellular calcium levels, AMPK, and autophagy may be ideal therapeutic targets, improving therapeutic prospects for the millions of people facing neurodegenerative disorders. 